\title{
Analysis of vaccine loss due to temperature change
}

\author{
Análise da perda de vacinas por alteração de temperatura \\ Análisis de pérdida de vacuna por cambio de temperatura
}

Flávia dos Santos Patine'

ORCID: 0000-0001-6103-2477

Luciano Garcia Lourenção"

ORCID: 0000-0002-1240-4702

Anneliese Domingues Wysocki"' ORCID: 0000-0002-8381-9999

Maria de Lourdes Sperli Geraldes Santos' ORCID: 0000-0001-6110-619X

Isabela Cristina Rodrigues ${ }^{\text {IV }}$ ORCID: 0000-0002-5209-4286

Silvia Helena Figueiredo Vendramini' ORCID: 0000-0003-3061-0355

'Faculdade de Medicina de São José do Rio Preto. São José do Rio Preto, São Paulo, Brazil.

"Universidade Federal do Rio Grande. Rio Grande,

Rio Grande do Sul, Brazil.

I'Universidade Federal do Mato Grosso do Sul. Três Lagoas,

Mato Grosso do Sul, Brazil.

"Secretaria de Estado da Saúde de São Paulo,

São José do Rio Preto, São Paulo, Brazil.

How to cite this article:

Patine FS, Lourenção LG, Wysocki AD, Santos MLSG, Rodrigues IC, Vendramini SHF. Analysis of vaccine loss due to temperature change.

Rev Bras Enferm. 2021;74(1):e20190762. doi: http://dx.doi.org/10.1590/0034-7167-2019-0762

Corresponding author:

Flavia dos Santos Patine

E-mail: patineflavia@hotmail.com

EDITOR IN CHIEF: Dulce Barbosa ASSOCIATE EDITOR: Hugo Fernandes

\section{ABSTRACT}

Objectives: to analyze vaccine losses in a Health Region in the Northwest of São Paulo. Methods: retrospective cross-sectional study with secondary data obtained from Temperature Change Notification Forms used by the Epidemiological Surveillance Group XXIX of São José do Rio Preto between 2010 and 2017. Descriptive and inferential analysis were performed using multiple linear regression and significance level of $95 \%$. Results: in total, 341 notifications of temperature changes were analyzed, of which $70.1 \%$ were caused by structural reasons, $57.8 \%$ in industrial refrigerators and $91.2 \%$ in primary care services. Of the doses that suffered a change in temperature, $41.4 \%$ were lost and $58.6 \%$ were administered to the population. The highest percentage of lost doses compared to those applied occurred in smaller municipalities, although they reported less. Conclusions: nursing workers who work in vaccination rooms should make efforts to prevent temperature changes and avoid losses and higher public expenses.

Descriptors: Refrigeration; Vaccines; Immunization; Disease Prevention; Health Care.

\section{RESUMO}

Objetivos: analisar as perdas de vacinas em uma Região de Saúde do Noroeste paulista. Métodos: estudo transversal retrospectivo, com dados secundários obtidos das fichas de notificação de alteração de temperatura utilizadas pelo Grupo de Vigilância Epidemiológica XXIX de São José do Rio Preto, entre 2010 e 2017. Foi realizada análise descritiva e inferencial, utilizando regressão linear múltipla e nível de significância de $95 \%$. Resultados: foram analisadas 341 notificações de alteração de temperatura, sendo $70,1 \%$ causadas por motivos estruturais, 57,8\% em refrigeradores industriais e $91,2 \%$ em serviços de atenção básica. Das doses que sofreram alteração de temperatura, 41,4\% foram perdidas e 58,6\% foram administradas na população. $\mathrm{O}$ maior percentual de doses perdidas em relação às aplicadas ocorreu em municípios menores, apesar de eles notificarem menos. Conclusões: os trabalhadores de enfermagem que atuam em salas de vacinação devem se empenhar para prevenir alterações de temperatura, evitando perdas e aumento dos gastos públicos. Descritores: Refrigeração; Vacinas; Imunização; Prevenção de Doenças; Atenção à Saúde.

\section{RESUMEN}

Objetivos: analizar las pérdidas de vacunas en una Región de Salud del Noroeste de São Paulo. Métodos: estudio transversal retrospectivo, con datos secundarios obtenidos de los formularios de notificación de cambios de temperatura utilizados por el Grupo XXIX de Vigilancia Epidemiológica de São José do Rio Preto entre 2010 y 2017. Se realizó el análisis descriptivo e inferencial y se utilizó la regresión lineal múltiple y nivel de significancia del 95\%. Resultados: se analizaron 341 notificaciones de cambios de temperatura, de las cuales el $70,1 \%$ fueron por motivos estructurales, el $57,8 \%$ en frigoríficos industriales y el $91,2 \%$ en los servicios de atención primaria. De las dosis que sufrieron un cambio de temperatura, el $41,4 \%$ se perdieron y el $58,6 \%$ se administraron a la población. El mayor porcentaje de dosis perdidas en comparación con las aplicadas se produjo en los municipios más pequeños, aunque informaron menos. Conclusiones: los trabajadores de enfermería que laboran en las salas de vacunación deben esforzarse por prevenir cambios de temperatura, evitando pérdidas y aumento de los gastos públicos.

Descriptores: Refrigeración;Vacunas; Inmunización; Prevención de Enfermedades; Atención a la Salud. 


\section{INTRODUCTION}

Vaccination is a method of protection with excellent cost-benefit ratio, constitutes a priority prevention action by primary health care and has high impact on the health of the population. In the last decades, vaccines have changed the epidemiological profile of vaccine-preventable diseases, reducing the number of cases and the costs for hospitalization and treatment ${ }^{(1-2)}$.

As vaccines are thermolabile products, they must be kept at controlled and ideal temperatures to maintain their immunogenicity and effectiveness. This requires conservation care performed by the nursing team, under the nurse's management. Although the ideal temperature to prevent deterioration is specified by the manufacturer, the stability of immunobiologicals can also be altered by brightness, humidity and type of vaccine strain ${ }^{(3-4)}$.

Aiming at the adequate conservation of immunobiologicals, in 1973 the Ministry of Health instituted the National Immunization Program (NIP), responsible for the national coordination of immunization actions in a central, in a synchronized and rational way. A logistics system named Cold Chain with qualified professionals, equipment and protocols for receiving, storing, conserving, handling, distributing and transporting immunobiologicals, in an appropriate manner(4-5).

The Cold Chain ensures that the immunogenic characteristics of the immunobiologicals are maintained, along the path between the producing laboratory and the administration. Thus, it is necessary that immunobiologicals are adequately refrigerated, in all instances of storage ${ }^{(5)}$.

In order to guarantee the immunogenic capacity of immunobiological agents, they must be kept at a local temperature between $+2^{\circ} \mathrm{C}$ and $+8^{\circ} \mathrm{C}$ within the expiration date specified on the bottle, as recommended by the NIP. Therefore, daily temperature control, recording and monitoring of the equipment are essential at the various storage levels. In case of temperature changes, the maximum, minimum and moment temperatures reached are taken into account, as well as the period during which the immunobiological remained at these temperatures $s^{(4-7)}$.

Weaknesses related to the refrigeration process, such as improper handling and equipment defects or lack of electricity, can compromise the potency and effectiveness of immunobiologicals. Therefore, they are put under suspicion and analysis and/or retest processes are performed based on guidelines of the NIP general coordination. After such procedures, the outcomes resulting from the temperature change will be the use or discard of the immunobiological $^{(5)}$.

In the state of São Paulo, when an immunobiological agent suffers a temperature change at the local/municipal level, the Temperature Change Notification Form is completed, then sent to the regional level (Epidemiological Surveillance Group - ESG), which will forward it to the state level (Epidemiological Surveillance (enter - ESC), where it will be analyzed for definition of the conduct to be adopted.

Studies show that failure to comply with vaccine conservation standards for errors or failures at the local level is common, generate unusability and dose losses, and cause financial and work process losses, which affect the quality of health services ${ }^{(7-9)}$. Therefore, studying the loss of vaccines due to temperature changes will help to identify the determinants of the problem and define measures to prevent losses, thereby supporting the work of nursing team in vaccination rooms and providing greater safety in the storage of immunobiologicals.

\section{OBJECTIVES}

To analyze vaccine losses in a Health Region in the Northwest of São Paulo.

\section{METHODS}

\section{Ethical aspects}

Prior to data collection, the study was approved by the Research Ethics Committee of the Medical School of São José do Rio Preto.

\section{Study design, period and location}

Observational, cross-sectional retrospective study, guided by the STROBE Statement.

Notifications of vaccine temperature changes received by the Epidemiological Surveillance Group XXIX of São José do Rio Preto (ESG 29) between 2010 and 2017 were used.

The ESG 29 is part of one of the 28 regional centers of the "Prof Alexandre Vranjac" Epidemiological Surveillance Center, responsible for the coordination and standardization of the Epidemiological Surveillance System in the state of São Paulo by planning, executing, managing and monitoring, at the state level, preventive and disease control measures, training human resources and developing research of interest to the public health system ${ }^{(10)}$.

This group is inserted in the Administrative Division of the Regional Health XV (DRS XV), considered one of the largest in the state of São Paulo. It covers 67 municipalities included in the Regional Intergovernmental Collegiate of Catanduva, José Bonifácio, Votuporanga and São José do Rio Preto that has 192 public vaccine rooms in operation ${ }^{(10)}$.

\section{Population or sample; inclusion and exclusion criteria}

In the study, all temperature change notification forms sent to the ESG 29 by the 192 vaccination rooms of its 67 municipalities between 2010 and 2017 were included. The following temperature change notification forms were excluded from the study: those that were not found, or with missing copies of the Immunization Division's opinion; those containing immunobiologicals for animals, such as vaccines against canine and feline rabies under responsibility of the Zoonosis department of municipalities; those containing homologous and heterologous serum, in which the dose depends on the individual's weight and the accident situation, with no way to measure the number of doses altered and lost due to temperature changes; those containing Palivizumab (humanized monoclonal antibody), immunobiological administered to prevent infection by the respiratory syncytial virus in premature infants ${ }^{(11)}$; those with the "recommended conduct" field in blank, with no response regarding the assessment by the 
ESC Immunization Division; and those containing only diluents, because they do not require refrigeration, so their potency and effectiveness are not affected by temperature changes.

Thus, the sample consisted of 341 notifications of temperature changes, as shown in Figure 1.

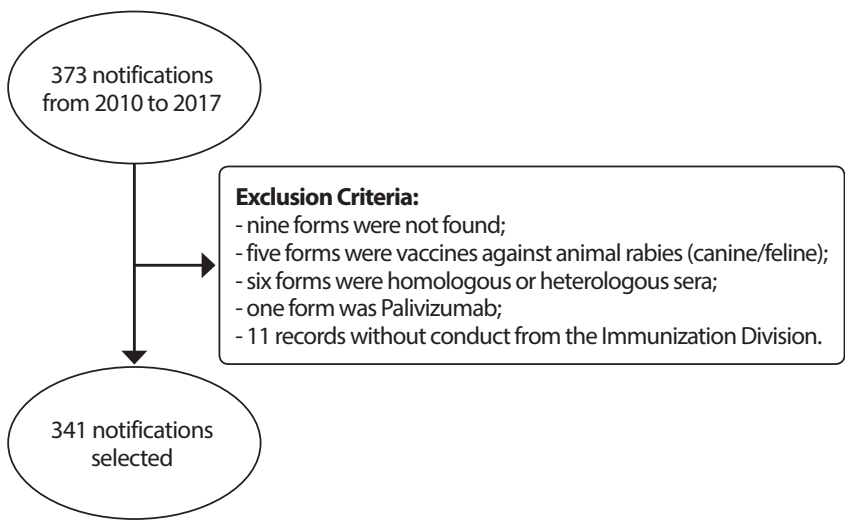

Figure 1 - Flowchart for the inclusion of temperature change notification forms of the Epidemiological Surveillance Group 29, São José do Rio Preto, São Paulo, Brazil, 2018

\section{Study protocol}

Data were collected using an instrument developed by the authors containing variables from the Temperature Change Notification Form, such as: municipality of notification, loss of vaccines (yes, no), period of occurrence of notification (January to March, April to June, July to September, October to December), reasons for temperature changes (structural - lack of electricity, problems with electrical installation in the health unit, changes in thermostat regulation; professionals - problems with transportation, equipment accidentally disconnected from the power grid or refrigerator door open; not informed); type of equipment (industrial refrigerator, domestic refrigerator, polypropylene thermal box or Styrofoam box with ice coils); notification service (Primary Care: Basic Health Unit, Basic Family Health Unit, Health Center, Epidemiological Surveillance; Specialized Care: outpatient clinic, hospital, specialty center; Urgency/Emergency Unit; Prison Unit); data from the Brazilian Institute of Geography and Statistics (Portuguese acronym: IBGE) ${ }^{(12)}$ (classification of municipalities by number of inhabitants) and from the Health Information Portal of the Ministry of Health - DATASUS ${ }^{(13)}$ (number of vaccination rooms per municipality; health care services).

\section{Analysis of results and statistics}

To characterize the loss of vaccines due to temperature changes, descriptive and inferential statistical techniques were used from the crossing of the dependent variable "vaccine loss" with the independent variables: period of occurrence of notifications; reasons for temperature changes; type of equipment; classification of municipalities by number of inhabitants; number of vaccination rooms per municipality; and health care services, through application of the Multiple Linear Regression test.

The outcome of the analysis of notification forms was considered as follows: vaccine doses exposed to inadequate temperatures, doses lost (discarded after the temperature change) and doses used (administered after the temperature change).

For the analysis of the percentage of altered doses, lost doses and used doses after the temperature change in relation to the doses applied, the following were considered: total number of altered doses in the study period; total number of lost doses and total number of doses used after alteration during the study period; and total doses applied in the period by municipality. These were grouped into: up to 10,000 inhabitants; 10,001 to 50,000 inhabitants; 50,001 to 500,000 inhabitants.

The results of independence between variables were given through analysis between $\mathrm{p}$ values (zero to one), with a standard error of $5 \%(p \leq 0.05)$.

Although the notification form requests the number of immunobiologicals in number of doses, notifications were found with the number of vials. In these cases, the number of vials was transformed into number of doses by considering the presentation of vials, which varies over time and according to the manufacturer's laboratory. To this end, the following were considered: BCG vaccine: 10 doses; Hepatitis $B$ vaccine (recombinant): 10 doses; Hepatitis A vaccine: one dose; Polio vaccine 1 and 3 (weakened) - OPV: 25 doses; Polio vaccine 1, 2 and 3 (inactivated) - IPV: 10 doses; Human rotavirus vaccine G1P1 [8] (weakened) - VORH: one dose; Yellow fever vaccine (weakened): 10 doses; Influenza vaccine (fractionated, inactivated): 10 doses; Pneumococcal 23-valent vaccine (polysaccharide): one dose; 10-valent pneumococcal conjugate vaccine - Pneumo 10: one dose; Meningococcal C vaccine (conjugate): one dose; Haemophilus influenzae B (conjugate) vaccine: one dose; Rabies vaccine (inactivated): one dose; Chickenpox vaccine: one dose; Adult diphtheria and tetanus adsorbed vaccine - dT: 10 doses; Diphtheria, tetanus, pertussis, hepatitis $B$ (recombinant) and Haemophilus influenzae B (conjugate) vaccine - DTP / HB / Hib (Penta): one dose; Diphtheria, tetanus and pertussis adsorbed vaccine - DTP: 10 doses; Measles, mumps, rubella (weakened) vaccine - SCR (Triple viral): 10 doses; Measles, mumps, rubella and chickenpox vaccine (weakened) - Tetra Viral: one dose; Adult diphtheria, tetanus, (acellular) pertussis vaccine - dTPa: one dose; Childhood diphtheria, tetanus, (acellular) pertussis vaccine - dTPa: one dose; Human papillomavirus vaccine 6, 11, 16, 18 (recombinant) - HPV quadri: one dose.

\section{RESULTS}

As noted in Table 1, of the 341 temperature change notifications received by the ESG 29 during the study period, 239 (70.1\%) were due to structural reasons, such as lack of electricity, problems with electrical installation in the health unit, change in thermostat regulation; 76 (22.3\%) occurred for professional reasons (transportation problems, equipment accidentally disconnected from the power grid or refrigerator door open); 197 (57.8\%) occurred in industrial refrigerators; 146 (42.8\%) were notified by municipalities with more than 50 thousand inhabitants; and 311 (91.2\%) occurred in primary care services.

Notifications of vaccine losses were significantly higher in municipalities with more than 50,000 inhabitants $(p=0.020)$; municipalities with more than five vaccination rooms $(p=0.039)$; and in Primary Health Care services $(p<0.001)$ (Table 1). 
Table 1 - Characterization of temperature change notifications according to the year of notification, São José do Rio Preto, São Paulo, Brazil, 2018

\begin{tabular}{|c|c|c|c|c|c|c|c|c|c|c|c|c|c|c|c|c|c|c|c|c|c|c|c|c|c|c|}
\hline \multirow{3}{*}{ Variables } & \multicolumn{26}{|c|}{ Year of notification } \\
\hline & \multicolumn{3}{|c|}{2010} & \multicolumn{3}{|c|}{2011} & \multicolumn{3}{|c|}{2012} & \multicolumn{3}{|c|}{2013} & \multicolumn{2}{|c|}{2014} & \multicolumn{3}{|c|}{2015} & \multicolumn{3}{|c|}{2016} & \multicolumn{3}{|c|}{2017} & \multicolumn{3}{|c|}{ Total } \\
\hline & $\mathbf{n}$ & $\%$ & $\begin{array}{c}p \\
\text { value }\end{array}$ & $\mathbf{n}$ & $\%$ & $\begin{array}{c}p \\
\text { value }\end{array}$ & $\mathbf{N}$ & $\%$ & $\begin{array}{c}p \\
\text { value }\end{array}$ & $n$ & $\%$ & $\underset{\text { value }}{p}$ & n $\%$ & $\begin{array}{c}p \\
\text { value }\end{array}$ & $e^{n}$ & $\%$ & $\begin{array}{c}p \\
\text { value }\end{array}$ & $e^{n}$ & $\%$ & $\begin{array}{c}p \\
\text { value }\end{array}$ & $n$ & $\%$ & $\begin{array}{c}p \\
\text { value }\end{array}$ & $n$ & $\%$ & $\begin{array}{c}p \\
\text { value }\end{array}$ \\
\hline Notification Period & & & 0.053 & & & 0.280 & & & 0.437 & & & 0.398 & & 0.085 & & & 0.455 & & & 0.244 & & & 0.190 & & & 0.876 \\
\hline Jan-Mar & 9 & 28.2 & & 11 & 34.4 & & 6 & 15.8 & & 22 & 46.8 & & 1536.6 & & 12 & 21.8 & & 152 & 28.3 & & 14 & 32.6 & & 104 & 30.5 & \\
\hline Apr-Jun & 4 & 12.5 & & 3 & 9.4 & & 7 & 18.4 & & 6 & 12.8 & & $\begin{array}{ll}5 & 12.2\end{array}$ & & 16 & 29.1 & & 112 & 20.7 & & 5 & 11.6 & & 57 & 16.7 & \\
\hline Jul-Sep & 6 & 18.7 & & 8 & 25.0 & & 8 & 21.0 & & 12 & 25.5 & & 921.9 & & 15 & 27.3 & & 152 & 28.3 & & 8 & 18.6 & & 81 & 23.7 & \\
\hline Oct-Dec & 13 & 40.6 & & 10 & 31.2 & & 17 & 44.7 & & 7 & 14.9 & & 1229.3 & & 12 & 21.8 & & 122 & 22.6 & & 16 & 37.2 & & 99 & 29.0 & \\
\hline $\begin{array}{l}\text { Reasons for } \\
\text { Temperature Change }\end{array}$ & & & 0.015 & & & 0.359 & & & 0.564 & & & 0.310 & & 0.574 & & & 0.225 & & & 0.733 & & & 0.169 & & & 0.085 \\
\hline Structural & 20 & 62.5 & & 17 & 53.1 & & 33 & 86.8 & & 33 & 70.2 & & 2663.4 & & 41 & 74.5 & & 36 & 67.9 & & 33 & 76.7 & & 239 & 70.1 & \\
\hline Professional & 6 & 18.7 & & 12 & 37.5 & & 0 & - & & 13 & 27.7 & & 1229.3 & & 14 & 25.4 & & 122 & 22.6 & & 7 & 16.3 & & 76 & 22.3 & \\
\hline Uninformed & 6 & 18.7 & & 3 & 9.4 & & 5 & 13.2 & & 1 & 2.1 & & 37.3 & & 0 & - & & 5 & 9.4 & & 3 & 7.0 & & 26 & 7.6 & \\
\hline Type of Equipment & & & 0.131 & & & 0.569 & & & 0.744 & & & 0.423 & & 0.190 & & & 0.291 & & & 0.559 & & & 0.094 & & & 0.848 \\
\hline Industrial & & 43.7 & & 12 & 37.5 & & 13 & 34.2 & & 31 & 66.0 & & 2663.4 & & 39 & 70.9 & & 36 & 67.9 & & 26 & 60.5 & & 197 & 57.8 & \\
\hline Domestic & 17 & 53.1 & & 19 & 59.4 & & 23 & 60.5 & & 14 & 29.8 & & 1229.3 & & 11 & 20.0 & & 132 & 24.5 & & 13 & 30.2 & & 122 & 35.8 & \\
\hline Others & 1 & 3.1 & & 1 & 3.1 & & 2 & 5.3 & & 2 & 4.3 & & 37.3 & & 5 & 9.1 & & 4 & 7.5 & & 4 & 9.3 & & 22 & 6.4 & \\
\hline $\begin{array}{l}\text { Classification of } \\
\text { Municipalities }\end{array}$ & & & 0.068 & & & 0.505 & & & 0.060 & & & 0.472 & & 0.840 & & & 0.415 & & & 0.453 & & & 0.652 & & & 0.020 \\
\hline Up to 10,000 inhab. & 8 & 25.0 & & 7 & 21.9 & & 7 & 18.4 & & 17 & 36.2 & & 2458.5 & & 27 & 49.1 & & 173 & 32.1 & & 15 & 34.9 & & 122 & 35.8 & \\
\hline 10,001 to 50,000 inhab. & 7 & 21.9 & & 7 & 21.9 & & 11 & 28.9 & & 12 & 25.5 & & 37.3 & & 8 & 14.5 & & 132 & 24.5 & & 12 & 27.9 & & 73 & 21.4 & \\
\hline $\begin{array}{l}50,001 \text { to } 500,000 \\
\text { inhab. }\end{array}$ & 17 & 53.1 & & 18 & 56.2 & & 20 & 52.6 & & 18 & 38.3 & & 1434.1 & & 20 & 36.4 & & 23 & 43.4 & & 16 & 37.2 & & 146 & 42.8 & \\
\hline $\begin{array}{l}\text { umber of } \\
\text { Vaccination Rooms }\end{array}$ & & & 0.029 & & & 0.652 & & & 0.011 & & & 0.649 & & 0.591 & & & 0.942 & & & 0.333 & & & 0.749 & & & 0.039 \\
\hline 1 Room & 7 & 21.9 & & 2 & 6.2 & & 6 & 15.8 & & 11 & 23.4 & & 1639.0 & & 13 & 23.6 & & 9 & 17.0 & & 8 & 18.6 & & 72 & 21.1 & \\
\hline 2 a 5 Rooms & 6 & 18.7 & & 10 & 31.2 & & 10 & 26.3 & & 17 & 36.2 & & 1229.3 & & 21 & 38.2 & & 22 & 41.5 & & 20 & 46.5 & & 118 & 34.6 & \\
\hline$>5$ Rooms & 19 & 59.4 & & 20 & 62.5 & & 22 & 57.9 & & 19 & 40.4 & & 1331.7 & & 21 & 38.2 & & 22 & 41.5 & & 15 & 34.9 & & 151 & 44.3 & \\
\hline Type of Health Service & & & 0.307 & & & 0.143 & & & 0.218 & & & 0.950 & & 0.033 & & & 0.072 & & & 0.066 & & & 0.026 & & & $<0.001$ \\
\hline Primary Care & 31 & 96.9 & & 28 & 87.5 & & 34 & 89.5 & & 46 & 97.9 & & 3278.0 & & 52 & 94.5 & & 48 & 90.6 & & 40 & 93.0 & & 311 & 91.2 & \\
\hline Other Services* & 1 & 3.1 & & 4 & 12.5 & & 4 & 10.5 & & 1 & 2.1 & & $\begin{array}{ll}9 & 21.9\end{array}$ & & 3 & 5.4 & & 5 & 9.4 & & 3 & 7.0 & & 30 & 8.8 & \\
\hline
\end{tabular}

Note: *Specialized Care: outpatient clinic, hospital, specialty center; Urgency/Emergency Unit; Prison Unit.

The highest number of notifications of temperature changes occurred in years 2015 (55 occurrences - 16.1\%) and 2016 (53 occurrences - 15.5\%). Two hundred and eighty-five (83.6\%) notifications resulted in loss of immunobiologicals (Table 2 ).

Notifications of temperature changes comprised 398,336 doses of vaccines throughout the period, with a higher concentration of doses in 2015 (21.3\%), 2016 (15.6\%), 2017 (13.3\%) and 2010 (13.1\%). Of this total, 20,608 (41.4\%) doses were lost/ unused (Table 3).

As seen in Table 4, the loss of vaccine doses resulting from temperature changes in municipalities of the ESG 29 represents $2.1 \%$ of the total doses applied in the whole region. In addition, $3.0 \%$ of doses used suffered temperature changes before administration. The percentage of lost doses in relation to those applied was higher in smaller municipalities (up to 10,000 inhabitants), although they reported less.

Nine municipalities, which represent $13.4 \%$ of the total municipalities in the ESG 29, did not report temperature changes during the study period. They were considered "silent" municipalities, that is, municipalities that have vaccination rooms, but did not report any occurrence in temperature changes and for unknown reasons. Most of these municipalities (77.8\%) have up to 10,000 inhabitants, only one vaccination room and together, add up to 214,668 doses of vaccines applied between 2010 and 2017. Two municipalities have 10,001 to 50,000 inhabitants, three vaccination rooms and applied 165,342 doses of vaccines in the period.

Table 2 - Description of vaccine losses according to the year of notification, São José do Rio Preto, São Paulo, Brazil, 2018

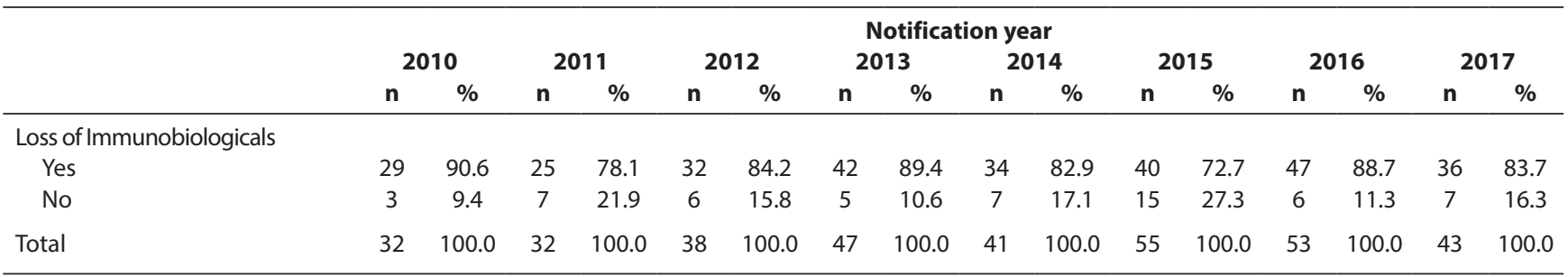


Table 3 - Description of doses lost and used in relation to changed doses by notification year, São José do Rio Preto, São Paulo, Brazil, 2018.

\begin{tabular}{ccccccc}
\hline $\begin{array}{c}\text { Notification } \\
\text { Year }\end{array}$ & $\begin{array}{c}\text { Number of } \\
\text { Notifications }\end{array}$ & $\begin{array}{c}\text { Total } \\
\text { Doses }\end{array}$ & \multicolumn{2}{c}{ Lost Doses } & \multicolumn{2}{c}{ Doses Used } \\
2010 & 32 & 52,245 & 18,701 & 35.8 & 33,544 & $64.2 \%$ \\
2011 & 32 & 29,773 & 13,204 & 44.3 & 16,569 & 55.6 \\
2012 & 38 & 25,151 & 9,271 & 36.9 & 15,880 & 63.1 \\
2013 & 47 & 48,784 & 19,230 & 39.4 & 29,554 & 60.6 \\
2014 & 41 & 42,754 & 19,591 & 45.8 & 23,163 & 54.2 \\
2015 & 55 & 84,707 & 20,104 & 23.7 & 64,603 & 76.3 \\
2016 & 53 & 61,974 & 34,573 & 55.8 & 27,401 & 44.2 \\
2017 & 43 & 52,948 & 30,188 & 57.0 & 22,760 & 43.0 \\
Total & 341 & 398,336 & 164,862 & 41.4 & 233,474 & 58.6 \\
Mean & 42.6 & 49,792 & 20,608 & 41.4 & 29,184 & 58.6 \\
\hline
\end{tabular}

Table 4 - Description of altered, lost and used doses in relation to doses applied according to the classification of municipalities and notification, São José do Rio Preto, São Paulo, Brazil, 2018

\begin{tabular}{|c|c|c|c|c|c|c|c|c|c|}
\hline \multirow{2}{*}{$\begin{array}{l}\text { Classification of } \\
\text { municipalities }\end{array}$} & \multirow{2}{*}{$\begin{array}{l}\text { Number of } \\
\text { municipalities }\end{array}$} & \multirow{2}{*}{$\begin{array}{c}\text { Number of } \\
\text { notifications }\end{array}$} & \multirow{2}{*}{$\begin{array}{c}\text { Total doses } \\
\text { applied } \\
\text { no }^{\circ}\end{array}$} & \multicolumn{2}{|c|}{$\begin{array}{c}\text { Altered } \\
\text { doses }\end{array}$} & \multicolumn{2}{|c|}{$\begin{array}{l}\text { Lost doses } \\
\text { after alteration }\end{array}$} & \multicolumn{2}{|c|}{$\begin{array}{l}\text { Doses used afte } \\
\text { alteration }\end{array}$} \\
\hline & & & & $n^{\circ}$ & $\%$ & $n^{\circ}$ & $\%$ & $n^{\circ}$ & $\%$ \\
\hline Up to 10,000 inhab. & 40 & 122 & $1,207,708$ & 119,795 & 9.9 & 60,605 & 5.0 & 79,194 & 6.6 \\
\hline 10,001 to 50,000 inhab. & 23 & 73 & $2,001,816$ & 85,141 & 4.2 & 34,808 & 1.7 & 60,171 & 3.0 \\
\hline 50,001 to 500,000 inhab. & 4 & 146 & $4,526,554$ & 193,400 & 4.3 & 69,449 & 1.5 & 94,109 & 2.1 \\
\hline Total & 67 & 341 & $7,736,078$ & 398,336 & 5.1 & 164,862 & 2.1 & 233,474 & 3.0 \\
\hline Mean & & 113.7 & $2,578,693$ & $132,778.7$ & 5,1 & 54,954 & 2.1 & $77,824.7$ & 3.0 \\
\hline
\end{tabular}

\section{DISCUSSION}

The Pan American Health Organization (PAHO) and World Health Organization (WHO) have shown concern about the vaccine storage system in all countries ${ }^{(9,14)}$. Although the loss of vaccines is expected across the Cold Chain, it is important to know if the loss could be prevented and how to avoid it ${ }^{(1,9)}$.

The increase in dose losses that occurred between October and March from year 2011 until 2014 and in 2017 may be related to climatic conditions with higher rainfall and frequent episodes of power outage ${ }^{(15)}$. This hypothesis is reinforced by the high frequency of losses for structural reasons, such as lack of power without prior communication after rainfalls, lightning strikes and storms, disconnection of the circuit breaker in the electrical distribution box or by unknown causes.

The disconnection of the circuit breaker in vaccination rooms can happen due to the lack of an alert to not turn it off ${ }^{(16-17)}$, even though the NIP recommends putting the warning "Do not disconnect" in the power distribution board and the power switches that supply the refrigerators in the vaccination rooms and / or the Cold Chain ${ }^{(4)}$.

Adversities related to electricity and refrigeration are frequent in developing countries. Therefore, monitoring the storage, handling and temperature stability of vaccines is important and can contribute to search for low-cost solutions that meet the needs of these countries and / or favor the development of more stable immunobiologicals $s^{(1,9,14,16)}$.

Other structural reasons such as problems with electrical installation in the units and defects in refrigeration appliances are reported in the literature and show the precarious conditions of basic health units and the lack of preventive maintenance of equipment needed for the stability of the Cold Chain ${ }^{(2,7,17-18)}$.
Among the professional reasons leading to the loss of vaccines, are the lack of electricity with prior communication; changes in the regulation of the equipment's thermostat; changes during transport; equipment disconnected from the power grid by accident; and refrigerator door open. Human failures compromise the quality of service and the conservation of vaccines, even with modern and good quality equipment ${ }^{(2,16,17-19)}$.

Studies conducted in northeastern Brazil have evidenced several flaws in the practice of professionals in vaccination rooms that contribute to the exposure of immunobiologicals to temperature variations, such as the lack of thermometers for monitoring the temperature of thermal boxes; do not replacing reusable ice in late morning / early afternoon, together with the failure to prepare the ice coils; and errors referring to the internal organization of domestic refrigerators that can contribute to the increase in temperature, in case of power cuts or defects in refrigerated ${ }^{(2,17,19)}$. In order to minimize these failures, as of the second half of 2010, the ESG 29 increased the training offer for vaccination room professionals.

On the other hand, a study conducted in Basic Health Units in the city of São Paulo suggests that the Cold Chain is being fully used, and it is not possible to accommodate new vaccines incorporated into the $\mathrm{PNI}$, a situation that worsens during vaccination campaigns; and detects other situations that compromise the quality of immunobiologicals, such as maintaining the temperature outside the manufacturer's recommendations and improper cleaning of refrigerators and thermal boxes. For the authors, despite implying additional costs, there has been a greater frequency of transport of routine vaccines to Basic Health Units in recent years with the purpose to avoid overcrowding of the Cold Chain when new vaccines are introduced, as well as loss of immunobiologicals as a result of power outages, common in some units ${ }^{(16)}$.

The literature also reports other compromising situations in relation to the work process in the Cold Chain, such as not providing exclusive refrigerators for the storage of vaccines; absence of thermometers to record minimum and maximum temperatures; worn out equipment; vaccination rooms and refrigerators exposed to high sunlight; lack of control and record of equipment temperature; inadequate distance between the coolers and the wall; performance of professionals without adequate training and knowledge in vaccination rooms $\mathrm{s}^{(2,16-18)}$.

A study conducted in Spain revealed that problems with vaccine conservation are not exclusive to Brazil. In Madrid, 23.3\% of public health units did not perform daily temperature control ${ }^{(20)}$. In Valencia, $75.0 \%$ of health centers did not register temperature control on a daily basis; there was food in $33.8 \%$ of refrigerators and, in $39.7 \%$ of refrigerators, vaccines were not organized correctly ${ }^{(21)}$.

The temperature alteration does not necessarily imply changes in the physical characteristics of the product, and sometimes is not identified the loss of its ability to protect against disease ${ }^{(2,20)}$. However, if changes in vaccine properties occur, there may be a higher morbidity and mortality from vaccine-preventable diseases, as occurred with pertussis rates in the United States in 2011 (22). 
The largest number of notifications by more populous municipalities may be related to the better structure of the surveillance system, as these municipalities generally have exclusive teams for epidemiological surveillance actions, greater financial investment in the Cold Chain and in professional training, and organize themselves better for monitoring and supervising the conservation of immunobiologicals. Smaller municipalities, on the other hand, have fewer professionals, report less or often do not report, raising the suspicion that the lack of notification may be a result of underreporting and not of the absence of temperature alteration occurrences.

The literature indicates that small towns have more vaccination rooms in critical situations and relates this fact with difficulties of allocation and training of professionals, who often have a temporary bond. This generates high turnover and makes it difficult to reach the necessary professional engagement in vaccination room activities. In addition, nurses in these municipalities often assume several responsibilities in the health unit, accumulating functions that can impair the performance in vaccination rooms, compromise the control of conservation of immunobiologicals and generate failures in the notification process of cases of temperature alterations ${ }^{(2,23)}$.

Possible cases of underreporting are addressed in studies showing a greater occurrence of errors in the handling of vaccines than recorded, although adequate refrigeration is always offered as a guarantee. Underreporting episodes of temperature change generate concern because if immunobiologicals have been exposed to non-standard temperatures and there was no notification, they were used in the population ${ }^{(7,14)}$.

Studies conducted in southeastern and northeastern states of Brazil had the worst percentages of assessment regarding professional conduct in the face of temperature changes, showing the lack of communication of occurrences to higher instances under the allegation of ignorance of the immunobiological record sheet under suspicion. These results show that underreporting compromises the functioning of the Cold Chain. Furthermore, according to studies, vaccines are not preserved at an ideal temperature $\left(+2 \mathrm{C}\right.$ to $\left.+8^{\circ} \mathrm{C}\right)$ until the manifestation of higher instances and discarded without any evaluation ${ }^{(2,7,17)}$.

In this context, possible cases of underreporting may cause bias in the results of this study, as the notification forms are filled out by professionals from the notifying municipalities who may distort or issue facts for various reasons (ignorance, fear of punishment, embarrassment, malpractice, negligence, among others). Thus, the training and adequate supervision of employees working in vaccination rooms of the health units are essential(23).

In 2010 and 2012, municipalities with more than five vaccination rooms presented a significant number of notifications with dose losses. Over the years, municipalities with fewer rooms started to notify more. This fact may be related to the training, guidance and frequent stimuli of the ESG 29 with the aim to make professionals aware of the need and importance of notifying temperature changes without punishment.

Still, the prevalence of occurrences of temperature changes and loss of vaccines in primary care services is expected and confirm the need to reorganize these services, as proposed by the Ministry of Health. It provides for the management of vaccination at the local level by basic health service units, including the Family Health
Strategy, health centers and epidemiological surveillance, where all vaccines on the calendar are administered ${ }^{(6,17-18)}$.

Despite the higher number of notifications in primary care services throughout the whole study period, specifically in years 2014 and 2017, vaccine loss in these services was significant. These results may be related to the introduction of the human papillomavirus vaccine 6, 11, 16, 18 (recombinant) for adolescents in 2014, and of the adult diphtheria, tetanus, (acellular) pertussis adsorbed vaccine for pregnant women and health professionals working directly with newborns in hospitals. In these cases, the Basic Health Units performed extramural vaccinations at schools and hospitals with a greater number of vaccine doses. In 2017, there were epizootics in the region with the risk of transmitting yellow fever to humans, which led municipalities to start vaccination at home, in rural, urban and border areas with participation of interns and employees from other sectors.

The authorization to use more than half of the altered vaccine doses that was given without retests to prove their potency can be justified by the high cost of this practice to the NIP, associated with the time required for this evaluation. For these reasons, retests are only performed when the notification of alteration involves a large number of doses ${ }^{(16,18)}$. Otherwise, the Immunization Division of the Epidemiological Surveillance Center of the state of São Paulo analyzes the situation based on notification data and issues an opinion on whether or not to use immunobiologicals. To this end, knowledge about the stability of each vaccine is taken into account, such as the rate of potency decline at a temperature, according to the WHO requirements for storage $\mathrm{e}^{(14)}$.

The development of more resistant immunobiologicals to adverse conditions or the creation of inexpensive devices that record exposure is suggested to avoid conditions that affect the effectiveness of a vaccine and the long and expensive retesting process ${ }^{(18)}$.

In China, a study revealed that storage of hepatitis $B$ vaccine outside the Cold Chain for up to three months did not change its effectiveness. The rates of seroconversion to anti-HBsAg in children vaccinated at birth with vaccines stored without and with refrigeration were $81.6 \%$ and $81.9 \%$, respectively ${ }^{(14)}$.

As there is no acceptable level of vaccine loss, it is impossible to affirm if the loss of vaccines due to temperature changes observed in this study was large or not. However, it was significant when compared to the number of doses that suffered changes and the doses applied, in addition to the high estimated cost.

According to the literature, Brazil has an annual cost of approximately one million Reais with vaccine losses, including technical and physical losses ${ }^{(18)}$. In Canada, there is an estimated loss of three million dollars a year resulting from alterations in the storage of immunobiologicals, while a fifth of Canadian health services failing to meet standards for the storage and proper handling of vaccines ${ }^{(22)}$.

These values point to the need for investments in the production of less thermolabile vaccines, training of professionals involved in the Cold Chain and the adequacy of vaccine storage. The savings generated with the decrease in losses justify the subsidy for investments in new technologies in the National Health System (Brazilian SUS), currently so burdened.

Nevertheless, it is essential that local levels define the logistics of the Cold Chain along with the State Health Departments in order to guarantee the adequacy of equipment and physical spaces, 
the needs for storage, stock and distribution, with preventive and corrective maintenance of equipment and electricity, through the use of generators and solar energy. The analysis and identification of errors to be corrected is fundamental to guarantee the safety of vaccines and the maintenance of vaccine coverage by services, because these are essential for disease prevention in the population.

\section{Study limitations}

The limitation of the study was its design. Since this is an evaluation of health services, the discussion of the results must consider the local reality. In addition, the weaknesses in completing the temperature change notification forms, such as lack of information on the reasons for the temperature change and the conduct of the Immunization Division compromise the quality of information and the definition of appropriate intervention actions. In addition, the scarcity of recent studies discussing the loss of vaccine doses due to temperature changes makes the deeper discussion of results difficult. The development of more comprehensive studies with national databases can contribute to deepen the discussion on the theme.

\section{Contributions to the field of nursing and public health}

The study contributes to public health by producing important information about failures in the process of storage and conservation of immunobiologicals in the Cold Chain, allowing the targeting of actions that minimize losses due to temperature changes, reduce possible risks to the population's health and avoid wasting financial resources from SUS. It also contributes to the Nursing team by pointing out the main causes of vaccine losses and favoring the management of conservation care for immunobiologicals. The results can strengthen surveillance and favor the development of interventions that improve the efficiency and effectiveness in the conservation of vaccines, thereby contributing to the performance of nursing in vaccination rooms.

\section{CONCLUSIONS}

The loss of vaccines due to temperature changes was significant when compared to the number of doses that suffered changes and doses applied, representing a high cost, both operational and financial. Despite the weaknesses inherent in the notification process, especially related to the proper completion of temperature change notification forms, the surveillance system proved to be important to ensure the quality and safety of immunobiologicals made available to the population.

In conclusion, preventing temperature changes in immunobiologicals is fundamental to reduce financial and to guarantee the safe use of immunobiologicals, their potency and effectiveness in the prevention of population morbidity and mortality by vaccine-preventable diseases.

\section{REFERENCES}

1. Crosewski F, Larocca LM, Chaves MMN. [Avoidable losses of immunobiologicals in the local instance: reflections on the nursing work process]. Saúde Debate. 2018;42(116):203-13. doi: 10.1590/0103-1104201811616 Portuguese.

2. Oliveira VC, Gallardo MDPS, Arcêncio RA, Gontijo TL, Pinto IC. [Assessment of quality of vaccine storage and conservation in primary health care centers]. Ciên Saúde Coletiva. 2014;19(9):3889-98. doi: 10.1590/1413-81232014199.12252013 Portuguese.

3. Simões NCS, Santos IF, Oliveira VC, Guimarães EAA, Andrade HS. Analysis of vaccine losses by temperature changes in a Health Region from Minas Gerais State, Brazil. ABCS Health Sci[Internet]. 2020 [cited 2020 Jun 14];45:1261. Available from: https://www.portalnepas.org.br/ abcshs/article/view/1261

4. Ministério da Saúde (BR). Secretaria de Vigilância em Saúde. Departamento de Vigilância das Doenças Transmissíveis. Manual de normas e procedimentos para vacinação [Internet]. Brasília (DF): Ministério da Saúde; 2014 [cited 2020 Jun 14]. Available from: http://bvsms.saude. gov.br/bvs/publicacoes/manual_procedimentos_vacinacao.pdf

5. Ministério da Saúde (BR). Secretaria de Vigilância em Saúde. Manual de Rede de Frio do Programa Nacional de Imunizações [Internet]. 5. ed. Brasília (DF): Ministério da Saúde; 2017 [cited 2020 Jun 14]. Available from: http://www.saude.pr.gov.br/arquivos/File/rede_frio_2017_web_VF.pdf

6. Secretaria de Estado da Saúde de São Paulo. Centro de Vigilância Epidemiológica "Prof. Alexandre Vranjac". Norma técnica do programa de imunização [Internet]. São Paulo: SESP; 2016 [cited 2020 Jun 14]. Available from: http://www.saude.sp.gov.br/ cve-centro-de-vigilancia-epidemiologica-prof--alexandre-vranjac/publicacoes/norma-tecnica-do-programa-de-imunizacao.

7. Raglione D, Bezerra GAM, Lopes MH, Nerger MLBR, Guimarães TC, Sartori AMC. [Evaluation of the cold chain for vaccine conservation in primary healthcare centers in the South and Midwest regions of São Paulo city, Brazil, in 2011-2012]. Epidemiol Serv Saúde. 2016;25(1):6574. doi: $10.5123 /$ S1679-49742016000100007 Portuguese.

8. Oliveira VC, Gallardo MDPS, Cavalcante RB, Arcêncio RA, Pinto IC. Weaknesses of vaccine storage in Primary Healthcare Centers. Rev Bras Enferm. 2015;68(2):291-6. doi: 10.1590/0034-7167.2015680215i

9. Samad SA. Perdas de vacinas: razões e prevalência em quatro unidades federadas do Brasil [Dissertação] [Internet]. São Paulo: Universidade Federal de São Paulo; 2011 [cited 2020 Jun 14]. Available from: http://repositorio.unifesp.br/handle/11600/9923

10. Secretaria de Estado da Saúde de São Paulo. Centro de Vigilância Epidemiológica "Prof. Alexandre Vranjac". Imunização [Internet]. 2019 [cited 2020 Jun 14]. Available from: http://www.saude.sp.gov.br/cve-centro-de-vigilancia-epidemiologica-prof.-alexandre-vranjac/ areas-de-vigilancia/imunizacao/ 
11. Ministério da Saúde (BR). Secretaria de Atenção à Saúde. Portaria SAS/MS n 522, de 13 de maio de 2013. Aprova o protocolo de uso do Palivizumabe [Internet]. 2013 [cited 2020 Jun 14]. Avaiable from: http://bvsms.saude.gov.br/bvs/saudelegis/sas/2013/prt0522_13_05_2013.html.

12. Instituto Brasileiro de Geografia e Estatística (IBGE). População [Internet]. 2018 [cited 2020 Jun 14]. Available from: https://ww2.ibge.gov.br/ home/mapa_site/mapa_site.php\#populacao

13. Ministério da Saúde (BR). DATASUS. Informações de Saúde [Internet]. 2018 [cited 2020 Jun 14]. Available from: http://tabnet.datasus.gov.br/ cgi/deftohtm.exe?pni/cnv/dpnisp.def

14. Organização Mundial da Saúde (OMS). Termoestabilidade das vacinas. Programa Global para vacinas e imunizações. Genebra: OMS; 1998.

15. Centro integrado de informações agrometeorológicas de São Paulo (CIIAGRO). Monitoramento Climatológico: Início da Estação EMA: 08/03/2008 até 26/11/2018. Município: São José do Rio Preto (EMA) - SP [Internet]. 2018 [cited 2020 Jun 14]. Available from: http://www. udop.com.br/download/estatistica/economia_chuvas/2008a2018_historico_sjose_rio_preto.pdf

16. Pereira DDS, Neves EB, Gemelli M, Ulbricht L. [Analysis of the utilization rate and loss of vaccines in the national immunization program]. Cad Saúde Colet. 2013;21(4):420-4. doi: 10.1590/S1414-462X2013000400010 Portuguese.

17. Santana RS. Avaliação da qualidade de conservação das vacinas da rede básica de saúde de um município do nordeste brasileiro [Dissertação] [Internet]. São Luís: Universidade Federal do Maranhão; 2015 [cited 2020 Jun 14]. Available from: https://tedebc.ufma.br/jspui/ handle/tede/1024

18. Ribeiro DO, Castro F, Ferreira GC, Santos JC, Coutinho RMC. [The equipment maintenance and storage of vaccines in the Basic Health Units of the Southern District of Campinas]. J Health Sci Inst [Internet]. 2010 [cited 2020 Jun 14];28(1):21-8. Available from: https://www.unip.br/ presencial/comunicacao/publicacoes/ics/edicoes/2010/01_jan-mar/V28_n1_2010_p21-28.pdf Portuguese.

19. Siqueira LG, Martins AMEBL, Versiani CMC, Almeida LAV, Oliveira CS, Nascimento JE, et al. [Assessment of the organization and operation of vaccine rooms in primary health care in Montes Claros, Minas Gerais, Brazil, 2015]. Epidemiol Serv Saúde. 2017;26(3):557-68. doi: 10.5123/ S1679-49742017000300013 Portuguese.

20. Arbiza PA, Vicente RA, Rábago MLG, Rojas VD, Molina PO, Pardo JRJ. Cadena del frío para la conservación de las vacunas en los centros de atención primaria de un area de Madrid: mantenimiento y nível de conocimientos. Rev Esp Salud Pública. 2002 [cited 2020 Jun 14];76(4):333-46. Available from: http://scielo.isciii.es/pdf/resp/v76n4/original6.pdf

21. Hueso BC, Sánchez OR, Pérez IC, Peiró S. La cadena de frío vacunal en un departamento de salud de la Comunidad Valenciana. Gac Sanit. 2009;23(2):139-43. doi: 10.1016/j.gaceta.2008.03.003

22. Parmar D, Baruwa EM, Zuber P, Kone S. Impact of wastage on single and multi-dose vaccine vials: Implications for introducing pneumococcal vaccines in developing countries. Hum Vaccin. 2010;6(3):pii: 10397. doi: 10.4161/hv.6.3.10397

23. Ribeiro AB, Melo CTP, Tavares DRS. [The importance of the nurse role in the vaccination room: an integrative review]. Rev Enferm UFJF. 2018;3(1):37-44. doi: 10.34019/2446-5739.2017.v3.3914 Portuguese. 